\title{
Biochar and humus sediment mixture attenuates crude oil-derived PAHs in a simulated tropical ultisol
}

\author{
Nnanake-Abasi O. Offiong ${ }^{1,2,3}$ (D) Edu J. Inam ${ }^{1,2} \cdot$ Helen S. Etuk $^{1,2} \cdot$ Joseph P. Essien $^{1,4} \cdot$ Utibe A. Ofon $^{4}$. \\ Christian C. Una ${ }^{5}$
}

Received: 29 April 2020 / Accepted: 20 October 2020 / Published online: 30 October 2020

(c) Springer Nature Switzerland AG 2020

\begin{abstract}
The potential of sewage sludge-derived biochar and humus mixtures for attenuation of polycyclic aromatic hydrocarbons (PAHs) in crude oil contaminated soil was evaluated. Laboratory-scale experiments involving ultisol samples spiked with crude oil, sewage sludge-derived biochar, and mixed biochar with humus sediment were monitored for removal of PAHs at the intervals of 1,6 , and 12 months. The results revealed that out of the three biochar products obtained at different pyrolysis temperatures: 500,700 , and $900^{\circ} \mathrm{C}$ (designated $\mathrm{BC} 500, \mathrm{BC} 700$, and $\mathrm{BC} 900$, respectively), $\mathrm{BC} 700$ recorded desirable properties and acceptable levels of PAHs suitable for soil amendment. Characterisation of the mixture for functional groups using Fourier transform infrared spectroscopy (FTIR) and surface morphology using scanning electron microscopy (SEM) revealed the presence of oxygenated and nitrogenated species that could support mineralisation of PAHs, increased surface area as well as pores to aid pollutant adsorption. The study revealed that the derived mixture demonstrated the potential to reduce the level of PAHs in contaminated soil. About $70 \%$ maximum reduction in the levels of total PAHs was recorded within 1 month for soil treated with the derived mixture in comparison to the control experiment.
\end{abstract}

Keywords Sewage sludge biochar · Humus sediment · PAHs · Tropical ultisol · Oil spill

\section{Introduction}

Treatment and reuse of wastes evolved as a way of solving the challenges of overpopulation and depleting material resources. Sewage sludge is a by-product of wastewater treatment. In many developing countries, a common method for the disposal of sewage and sewage sludge is landfilling and discharge into surface waters. These disposal methods result in gross contamination of the environment that may consequently lead to the spread of enteric diseases. According to Beecher [1], it is estimated that if some developing countries were to attain the levels of wastewater treatment obtained in developed countries, sewage sludge production (in metric tonnes) would be 2,852,972 (Nigeria); 4,069,339 (Brazil); 375, 191 (Cameroon); 1,617,928 (Ethiopia); 21,596 (Hungary); 956,062 (South Africa); and 1,523,506 (Turkey). Whereas, for some developed countries, the values of sewage sludge production (in metric tonnes) are 2,966,000 (China); 2,000,000 (Japan); 550 (Canada), 6,514,000 (USA); 2,000,000 (Germany); 1,500,000 (UK); and 1,500,000 (Netherlands). High sewage sludge volumes in developed countries are related

Electronic supplementary material The online version of this article (https://doi.org/10.1007/s42452-020-03744-5) contains supplementary material, which is available to authorised users.

$\triangle$ Edu J.Inam, eduinam@uniuyo.edu.ng| ${ }^{1}$ International Centre for Energy and Environmental Sustainability Research (ICEESR), University of Uyo, Uyo, Nigeria. ${ }^{2}$ Department of Chemistry, University of Uyo, Uyo, Nigeria. ${ }^{3}$ Present Address: College of New Energy and Environment, Jilin University, Changchun, P.R. China. ${ }^{4}$ Department of Microbiology, University of Uyo, Uyo, Nigeria. ${ }^{5}$ College of Chemistry and Chemical Engineering, Xi'an Shiyou University, Xi'an, Shaanxi Province, P.R. China. 
to high population size and availability of sewage treatment infrastructure. However, the handling of sewage and sewage sludge still remains a serious challenge in most urban cities globally [2-5]. This becomes more complicated because of stricter environmental regulations guiding the handling and disposal of sewage sludge and its effluents in those countries. The incineration method was later devised for the treatment of sewage sludge, but this is usually achieved at a very high cost [6]. Yet, an environmentally sustainable handling method has been suggested which incorporates ecological, economic, and social responsibilities [7]. In the current paradigm, materials utilisation and recovery are emphasised.

Furthermore, there is no single solution to the environmental and energy problems associated with sewage (sludge) management, thus leading to the advent of sustainable alternatives for waste materials utilisation. Examples of these include the utilisation of sludge wastes for the production of energy [8,9], building materials [4], fertilisers and soil conditioners [10], feedstock for the production of novel adsorbents for pollution reduction and metal extraction [11], amongst others. Another beneficial way of utilising sewage sludge is to valorise it into useful materials such as activated carbon [6] or biochar [12] for the remediation of pollutants. Sludge when pyrolysed produces a carbonaceous residue called biochar. The biochar, owing to its aromatic nature, high surface area, cation exchange capacity (CEC), micropore volume, and the presence of multi-functional polar groups serve as a good sorbent for pollutant adsorption as well as carbon dioxide sequestration $[13,14]$.

Crude oil and its derived products constitute many organic contaminants that could pose human and environmental health risks during spill events. Polycyclic aromatic hydrocarbons (PAHs) are amongst the most important class of crude oil-derived organic contaminants which are known to be persistent and classified as possible carcinogens. Remediation of sites contaminated with PAHs still receives wide attention by scientists and engineers in recent times because of stricter environmental regulations and the need to maintain healthy ecosystems. Soil amendment with different substrates and materials have been developed and applied to remediate sites contaminated with PAHs. Direct application of sewage sludge for remediation of contaminated sites is possible, but there are concerns that the sewage sludge may increase the levels of contaminants or introduce other types of contaminants such as trace metals [12]. Examples of these substrates and materials reported include organic fertilisers, microbial consortia, biochar, and bulking agents, amongst others [15-17].

Recently, great attention has been drawn towards the use of valorised waste biochar for remediation of PAHs and other organic contaminants in soils [14, 18-22]. The motivation lies in the need for resource recovery for sustainable environmental remediation $[23,24]$. Similarly, the role of humus substances on the fate and distribution of PAHs in soils has been evaluated [25-33]. However, under certain environmental conditions such as excess crude oil spills and soil characteristics, it is still unclear how humus substances and biochar interact with and/or influence the distribution of PAHs. Our previous reports highlighted the peculiarity of site-specific remediation approaches, especially in developing countries, and the need for sustainable methods [34, 35]. Furthermore, most studies focused on single or binary contaminant media; whereas, practical situations encountered often involve the complex mixture of contaminants such as crude oil spills which could contain multiple suits of PAHs [36]. In our recent study, we reported the possibility of a complementary role of humic substances in achieving low levels of PAHs in a freshwater tropical river sediment under medium anthropogenic stress [37]. However, as sediment mudflats may not be a renewable resource for remediation, we attempted to engineer, in the present study, a mixture combining both humus sediment and biochar obtained from sewage sludge. The objective was to evaluate the effect of humus sediment slurry on PAH distribution in sewage sludgederived biochar amended tropical ultisol under excess crude oil inoculation.

\section{Materials and methods}

\subsection{Materials}

Sewage sludge samples for the preparation of biochar were collected in May 2016 from a Sewage Treatment Plant (STP) located in Port Harcourt City, Nigeria. Appropriate permissions were obtained from the responsible authorities operating the STP before sampling commenced. The sewage treatment plant is operated based on the activated sludge process. There are no chemicals added during treatment, and the wastes are aerated to allow microbial proliferation. The plant is designed to treat about $180 \mathrm{~m}^{3}$ of sewage per day and industrial wastewaters are not treated with the sewage. The plant is operated at a 24-h residence time. Oxygen from atmospheric air is utilised as the active oxidising agent. The activated sludge is thereafter allowed to settle after several aerations, to biodegrade over $70 \%$ of the organics. This is followed by sedimentation with a residence time of $4 \mathrm{~h}$ and later transferred to a sludge holding tank where it is held for more than 21 days. During this period, more organics are transformed and degraded. The produced sludge is 
then drained and bagged. It was the drained and bagged sludge samples that were collected for use in this study.

The Bonny Light crude oil samples for simulation studies were collected between May 2016 and January 2017 from the Production Chemistry Department of Shell Petroleum Development Company of Nigeria, Port Harcourt. The crude oil samples were collected directly from wellheads of land production areas in the Niger Delta region without prior treatment. These samples were stored in cool dry conditions prior to use for experimental work. Surface soil $(0-10 \mathrm{~cm})$ samples for simulation studies were collected using stainless steel hand trowel between May 2016 and August 2018 from the Botanical Garden of the Department of Botany \& Ecological Studies, University of Uyo, Nigeria with no incidence of crude oil contamination. Soils of this study area are generally acidic $(\mathrm{pH}$ range $=3-5$ ) and classified as tropical ultisols based on previous studies [38-40]. Fresh soil samples were collected during each stage of the experiment. Humus sediment samples were collected from Eniong River located at Okopedi-Itu in Itu, Nigeria. The sediment samples have been well characterised in our previous reports for humic acid content [41], organic carbon content as well as its effects on PAH accumulation [37]. Freshly collected samples (1 week maximum) were used during simulation studies.

\subsubsection{Biochar preparation from sewage sludge}

The sewage sludge biochar was prepared under controlled conditions by pyrolysis of air-dried sewage sludge samples at three different temperatures: 500,700 , and $900^{\circ} \mathrm{C}$ represented by $B C 500, B C 700$, and $B C 900$, respectively. The biochar was prepared by pyrolysis under oxygenlimited conditions using a muffle furnace (Carbolite, Sheffield, UK). To ensure limited oxygen condition, the muffle furnace was purged with nitrogen for $5 \mathrm{~min}$ at the rate of $3 \mathrm{~L} / \mathrm{min}$ and then sealed. Before sealing off the reaction chamber, the sewage sludge feedstocks of adequate amounts were loaded in a wire mesh basket suspended in a sealed stainless-steel vessel with a perforated lid inside the muffle furnace. The pyrolysis was carried out for $1.5 \mathrm{~h}$ [42]. The heating rate employed was $5^{\circ} \mathrm{C} / \mathrm{min}$ [43]. Thereafter, the pyrolysed products (biochars) were removed from the muffle furnace and placed in a desiccator to cool. The biochars were then weighed and stored in plastic containers before use.

\subsubsection{Preparation of biochar-humus mixtures}

Materials used for the preparation of the biochar-humus mixture include the prepared biochar, humic acid (Sigma Aldrich, UK), humus sediment from Eniong River, and deionised water. Water content was maintained at 5\% $(w / w)$ throughout the experiment. The percentages of the other materials were determined at different stages of the experiments, using the elimination method. This was done in order to determine the optimum amount that would be required for high $\mathrm{PAH}$ attenuation efficiency.

\subsubsection{Soil microcosm experiment}

In detail, a batch experiment described by Li et al. [44] was adopted for the simulation studies. The first stage of the experiment comprised eight (8) soil samples and the mixtures of different proportions of humic sediment, crude oil, biochar, and commercial humic acid as presented in Table 1. The samples were stored under room temperature in an open top wooden box with perforated bottom.

The soil samples prior to use for simulation studies were air-dried, homogenised, and sieved $(2 \mathrm{~mm})$ to remove plant debris. This was followed by spiking of a specified level $(120 \mathrm{~mL}$ ) of crude oil samples (to achieve $2.9 \%$ contamination) and stirring. Then, samples were allowed to equilibrate for $24 \mathrm{~h}$ before adding the biochar-humus mixtures and $5 \%(\mathrm{w} / \mathrm{w})$ deionised water and stirred until all the substances mixed to form a semi-slurry. The abbreviation HSBC was used to denote the mixture of humus substances and the biochar. The first batch of the experimental set-up as detailed in Table 1 was monitored for PAHs for 1, 6, and 12 months. Soil sample without crude
Table 1 Contaminated soil and the composition of amended biochar used for soil remediation

\begin{tabular}{lll}
\hline S/N & Sample code & Composition \\
\hline 1 & A & Blank: Soil $(4 \mathrm{~kg})+$ crude oil $(120 \mathrm{~mL})$ \\
2 & B & Soil $(4 \mathrm{~kg})+$ crude oil $(120 \mathrm{~mL})+\mathrm{HA}(5 \mathrm{~g})$ \\
3 & C & Soil $(4 \mathrm{~kg})+$ crude oil $(120 \mathrm{~mL})+$ biochar $(5 \mathrm{~g})$ \\
4 & D & Soil $(4 \mathrm{~kg})+$ crude oil $(120 \mathrm{~mL})+\mathrm{HS}(5 \mathrm{~g})$ \\
5 & E & Soil $(4 \mathrm{~kg})+$ crude oil $(120 \mathrm{~mL})+\mathrm{HA}(5 \mathrm{~g})+\mathrm{HS}(5 \mathrm{~g})$ \\
6 & F & Soil $(4 \mathrm{~kg})+$ crude oil $(120 \mathrm{~mL})+$ biochar $(5 \mathrm{~g})+\mathrm{HA}(5 \mathrm{~g})$ \\
7 & G & Soil $(4 \mathrm{~kg})+$ crude oil $(120 \mathrm{~mL}) \mathrm{HS}(5 \mathrm{~g})+$ biochar $(5 \mathrm{~g})$ \\
8 & H & Soil $(4 \mathrm{~kg})+$ crude oil $(120 \mathrm{~mL})+\mathrm{HS}(5 \mathrm{~g})+\mathrm{HA}(5 \mathrm{~g})+$ biochar $(5 \mathrm{~g})$ \\
\hline
\end{tabular}

$H A$ humic acid, $H S$ humic sediment, Biochar obtained at $500^{\circ} \mathrm{C}$ pyrolysis temperature 
oil contamination was also analysed to serve as a control. All experiments were run in triplicates but analysed as composites following standard guidelines applicable to quantification of PAHs in soils [45-48].

\subsubsection{Surface characterisation and Fourier transform-infrared spectroscopy}

The determination of the surface functional groups was carried out using Fourier transform-infrared (FTIR) spectrophotometer (Fisher Thermoscientific, USA) following standard procedures. The spectra were recorded using $\mathrm{KBr}$ wafers in the range $4000-400 \mathrm{~cm}^{-1}$. The surface area and porosity analyses were carried out using micrometrics surface area and porosity analyser (Micromeritics Tristar 3000) by nitrogen adsorption method at $-77 \mathrm{~K}$. The surface area and pore volume were calculated by Brunauer-Emmet-Teller (BET) and t-plot methods, respectively. Pore size analysis was carried out to determine the distribution of pores of the adsorbent.

\subsubsection{Analysis of PAHs in samples}

PAHs were monitored in the crude oil sample, sewage sludge, control soil sample contaminated with crude oil only, simulated soil with biochar, humic sediment, and commercial humic acid using the gas chromatographymass spectrometric method described previously by Qin et al. [13] and Cao et al. [49]. The analysis involved the quantification of the 16 USEPA priority PAHs. Prior to instrumental analysis, samples were homogenised, airdried, and then sieved through a 100-mesh stainless sieve followed by Soxhlet extraction with dichloromethane as a solvent for $16 \mathrm{~h}$. Crude oil samples were extracted by liquid-liquid extraction using a separatory funnel. The extracts were concentrated to a volume of $1 \mathrm{~mL}$ by rotary vacuum evaporation and solvent exchanged to $n$-hexane. The clean-up procedure was carried out with a glass chromatographic column packed with anhydrous sodium sulphate, and silica gel/alumina (1:1 w/w). The column was conditioned with $3 \mathrm{~mL} n$-hexane and after the samples were loaded, the first fraction, containing aliphatic hydrocarbons, was eluted with $15 \mathrm{~mL} n$-hexane and the second fraction, containing PAHs was collected by eluting sequentially with $30 \mathrm{~mL} n$-hexane/dichloromethane (3:7 $\mathrm{v} / \mathrm{v})$. The PAHs containing extracts were concentrated to about $2 \mathrm{~mL}$ by a rotary evaporator and then transferred to GC-MS amber vials and reduced to $1 \mathrm{~mL}$ by a gentle nitrogen stream. The recoveries, limits of detection (LOD), and quantitation (LOQ) have been previously reported [37]. All experiments were run in triplicates but analysed as composites following standard guidelines applicable to quantification of PAHs in soils [45-48].

\subsubsection{Determination of effect of humus mixtures on the attenuating (bio)agents in crude oil simulated soils}

To determine the impact of biochar-humus sediment mixture on the quantity of total heterotrophic bacterial count (THBC) and density of the hydrocarbon utilising bacteria or crude oil degrading bacteria (COB) in the soil samples, $1 \mathrm{~g}$ of each soil sample was serially diluted and plated in sterile molten nutrient agar (Bacto) and modified mineral salt medium $\left[6 \mathrm{~g} \mathrm{~K}_{2} \mathrm{HPO}_{4}, 12 \mathrm{~g} \mathrm{NaCl}, 6 \mathrm{~g} \mathrm{KH}_{2} \mathrm{PO}_{4}, 6 \mathrm{~g}\left(\mathrm{NH}_{4}\right)_{2} \mathrm{SO}_{4}\right.$, $\left.2.6 \mathrm{~g} \mathrm{MgSO}_{4} \cdot 7 \mathrm{H}_{2} \mathrm{O} .0 .16 \mathrm{~g} \mathrm{CaCl}_{2} \cdot 2 \mathrm{H}_{2} \mathrm{O}, 7.5 \mathrm{~g} \mathrm{Agar} / \mathrm{L}\right]$ fortified with $1 \%$ crude oil, respectively, using the pour plate technique. The plates were allowed to set and incubated at room temperature $\left(26 \pm 1^{\circ} \mathrm{C}\right)$ for $24 \mathrm{~h}$. Samples were obtained at 6-day interval, and the process was repeated. Representative colonies that emerged following cultivation were quantified and reported as $\mathrm{CFUg}^{-1}$.

\section{Results and discussion}

\subsection{Profile of PAHs in samples of raw sludge and biochar}

The levels of PAHs in raw and pyrolysed sludge samples are presented in Table 2 . The concentrations of individual PAH suite and $\Sigma 16$ USEPA-PAHs varied with treatment

Table 2 Levels of PAHs in raw and pyrolysed sludge samples

\begin{tabular}{|c|c|c|c|c|}
\hline \multirow[t]{2}{*}{ Compound } & \multicolumn{4}{|c|}{ Levels (mg/kg) } \\
\hline & Raw sludge & BC500 & BC700 & BC900 \\
\hline Naphthalene (Naph) & $<0.001$ & 0.24 & 0.02 & 0.02 \\
\hline Acenaphthylene (Acy) & $<0.001$ & 0.01 & BDL & $\mathrm{BDL}$ \\
\hline Acenaphthene (Ace) & $<0.001$ & 0.03 & BDL & $\mathrm{BDL}$ \\
\hline Fluorene (Flu) & $<0.001$ & 0.06 & 0.01 & 0.01 \\
\hline Phenanthrene (Phen) & $<0.001$ & 0.07 & 0.01 & 0.01 \\
\hline Anthracene (Ant) & $<0.001$ & 0.17 & 0.02 & 0.02 \\
\hline Fluoranthene (Flt) & $<0.001$ & 0.04 & BDL & $\mathrm{BDL}$ \\
\hline Pyrene (Pyr) & $<0.001$ & 0.03 & 0.01 & 0.01 \\
\hline Chrysene (Chry) & $<0.001$ & 0.01 & 0.01 & 0.01 \\
\hline Benzo(a)anthracene (BaA) & $<0.001$ & BDL & 0.01 & 0.01 \\
\hline Benzo(b)fluoranthene (BbF) & $<0.001$ & 0.01 & 0.01 & 0.01 \\
\hline Benzo(k)fluoranthene (BkF) & 0.005 & 0.01 & 0.01 & 0.01 \\
\hline Benzo(a)pyrene (BaP) & $<0.001$ & 0.01 & 0.01 & 0.01 \\
\hline $\begin{array}{l}\text { Dibenzo(a,h)anthracene } \\
\text { (DbA) }\end{array}$ & $<0.001$ & 0.01 & BDL & $\mathrm{BDL}$ \\
\hline $\begin{array}{l}\text { Indeno(1,2,3-cd)pyrene } \\
\quad \text { (IndP) }\end{array}$ & $<0.001$ & $\mathrm{BDL}$ & 0.01 & 0.01 \\
\hline Benzo(g,h,i)perylene (BgP) & $<0.001$ & 0.01 & 0.01 & 0.01 \\
\hline ¿16USEPA-PAHs & 0.005 & 0.71 & 0.14 & 0.14 \\
\hline
\end{tabular}


temperature. Pyrolysis at $\mathrm{BC500}$ increased the concentrations of naphthalene (Naph), acenaphthylene (Acy), acenaphthene (Ace), fluorene (Flu), phenanthrene (Phen), pyrene (Pyr), and chrysene (Chry) in sludge. The concentration of benzo(a)anthracene $(\mathrm{BaA})$ was below the detectable limit in sludge pyrolysed at BC500 but increased after pyrolysis at $\mathrm{BC} 700$ and $\mathrm{BC} 900$ whilst dibenzo(a,h)anthracene (DbA) level increased after pyrolysis at $B C 500$. The total levels of PAHs ranged from $0.005 \mathrm{mg} / \mathrm{kg}$ in the raw sludge to $0.71 \mathrm{mg} / \mathrm{kg}$ in $\mathrm{BC} 500$, and $0.14 \mathrm{mg} / \mathrm{kg}$ in both $\mathrm{BC700}$ and BC900.

As sewage sludge has the potential to contain PAHs, it was necessary to, first of all, characterise its contamination level and evaluate its suitability to be applied in this study. As shown in Table 2, the levels obtained indicate very low contamination. Of the 16 USEPA's priority list of $\mathrm{PAH} s$, it was only benzo $(\mathrm{k})$ fluoranthene that was detected at $0.005 \mathrm{mg} / \mathrm{kg}$. At this contamination level, the sewage sludge could be used with no concern for accumulated PAHs. However, caution must be taken as other organic and inorganic contaminants may be present in sludge. High pyrolysis temperatures $\left(700-900^{\circ} \mathrm{C}\right)$ tend to increase the high molecular weight (HMW) PAHs level in ash biochar (Table 2), though the levels recorded are still within permissible limits of $1.5 \mathrm{mg} / \mathrm{kg}$ for application on soil [50]. The levels were also within the recommended levels $(<12 \mathrm{mg} / \mathrm{kg}$ ) by the German Federal Soil Protection agency as reported by Yang et al. [51]. Again, according to Dunnigan et al. [52], the USEPA maximum limit of PAH in sludge before soil application is $6 \mathrm{mg} / \mathrm{kg}$, and the results of the present study fell within the allowable range. Biochar prepared at a moderate pyrolysis temperature $\left(500-800^{\circ} \mathrm{C}\right)$ seems ideal as many of the pathogens would have been destroyed [53]; however, some organic matter may still be retained with enhanced surface property for sorption of pollutants. The increase in PAHs levels of the biochar was expected as PAHs are also products of pyrolysis of biomass. And high-temperature pyrolysis tends to increase their concentrations in produced biochars.

In this study, we observed a reduction in PAH levels in biochar produced at higher pyrolysis temperature $\left(900^{\circ} \mathrm{C}\right)$. A similar observation was reported by Hale et al. [54] who found that PAH levels in biochar could decrease with an increase in pyrolysis time and temperature. The authors concluded that there was no clear pattern of how PAHs were bound to different biochars based on their physicochemical properties. Given this disparity, it may be that at high pyrolysis temperature, PAHs tend to bind strongly to biochars, limiting their extraction with organic solvents [53]. The implication is that after application on soils, the binding affinity reduces, making extractability and detection easy because the interaction of biochar with soil components can promote PAH desorption. As a consequence, a higher concentration of PAHs was detected in soils treated with BC900 compared to BC500 and BC700 (Table 3). Furthermore, Chen et al. [55] illustrated that at high pyrolysis temperatures the mechanism of PAH (Naph) interaction with biochars is controlled by adsorption, whereas the partition mechanism dominates at low pyrolysis temperature.

\subsection{Characteristics of raw and pyrolysed sludge}

The results of the surface areas, pore characteristics, nitrogen adsorption-desorption isotherms, and pore size distribution of the pyrolysed sludge are presented in Table 4 and Fig. 1, respectively. The pyrolysed sewage sludge achieved the highest single-point surface area $\left(25.05 \mathrm{~m}^{2} / \mathrm{g}\right)$, BET surface area $\left(26.77 \mathrm{~m}^{2} / \mathrm{g}\right)$, Langmuir surface area $\left(111.95 \mathrm{~m}^{2} / \mathrm{g}\right)$, and t-plot external surface area $\left(30.52 \mathrm{~m}^{2} / \mathrm{g}\right)$. On the other hand, the non-pyrolysed sewage sludge achieved the lowest single-point surface area $\left(16.29 \mathrm{~m}^{2} / \mathrm{g}\right)$, BET surface area $\left(17.99 \mathrm{~m}^{2} / \mathrm{g}\right)$, and t-plot external surface area $\left(22.05 \mathrm{~m}^{2} / \mathrm{g}\right)$. The increase in surface area of sludge after pyrolysis could be related to the release of volatile organics which led to the generation of pores in the biochar structure [56]. Generally, biochar produced at high pyrolysis temperatures tends to have high surface areas [53]. Lu et al. [57] obtained a similar BET surface area $\left(24.73 \mathrm{~m}^{2} / \mathrm{g}\right)$ with the present work for a sludge-derived biochar obtained at $550^{\circ} \mathrm{C}$. In contrast, the BET surface area recorded in the present work is lower than those reported by Yao et al. [58]. The authors reported that sludge-derived biochar produced at $550{ }^{\circ} \mathrm{C}$ pyrolytic

Table 3 Effects of sludge pyrolysis temperature on the levels (mg/ $\mathrm{kg}$ ) of PAHs 1 month after soil treatment

\begin{tabular}{llll}
\hline Compound & $\mathrm{BC500}$ & $\mathrm{BC700}$ & $\mathrm{BC900}$ \\
\hline Naphthalene (Naph) & $\mathrm{BDL}$ & $\mathrm{BDL}$ & $\mathrm{BDL}$ \\
Acenaphthylene (Acy) & 0.01 & 0.03 & 0.02 \\
Acenaphthene (Ace) & 0.02 & 0.02 & 0.05 \\
Fluorene (Flu) & 0.06 & 0.04 & 0.12 \\
Phenanthrene (Phen) & 0.27 & 0.14 & 0.45 \\
Anthracene (Ant) & 0.07 & 0.06 & 0.15 \\
Fluoranthene (Flt) & $\mathrm{BDL}$ & 0.01 & 0.03 \\
Pyrene (Pyr) & 0.01 & 0.01 & 0.02 \\
Chrysene (Chry) & $\mathrm{BDL}$ & $\mathrm{BDL}$ & $\mathrm{BDL}$ \\
Benzo(a)anthracene (BaA) & 0.02 & $\mathrm{BDL}$ & 0.03 \\
Benzo(b)fluoranthene (BbF) & 0.01 & $\mathrm{BDL}$ & 0.01 \\
Benzo(k)fluoranthene (BkF) & $\mathrm{BDL}$ & $\mathrm{BDL}$ & $\mathrm{BDL}$ \\
Benzo(a)pyrene (BaP) & $\mathrm{BDL}$ & $\mathrm{BDL}$ & $\mathrm{BDL}$ \\
Dibenzo(a,h)anthracene (DbA) & 0.01 & $\mathrm{BDL}$ & 0.02 \\
Indeno(1,2,3-cd)pyrene (IndP) & 0.02 & $\mathrm{BDL}$ & 0.03 \\
Benzo(g,h,i)perylene (BgP) & 0.01 & $\mathrm{BDL}$ & 0.01 \\
$\Sigma 16 \mathrm{USEPA}-\mathrm{PAHs}$ & 0.51 & 0.31 & 0.94 \\
\hline
\end{tabular}


Table 4 Surface areas and pore characteristics of the fresh, aged, and pyrolysed sewage sludge

\begin{tabular}{llll}
\hline Parameters & Fresh sludge & $\begin{array}{l}\text { Aged sludge } \\
\text { after 6 months }\end{array}$ & $\begin{array}{l}\text { Pyrolysed } \\
\text { sludge at } \\
500{ }^{\circ} \mathrm{C}\end{array}$ \\
\hline Single point surface area $\left(P / P^{\circ}\right)\left(\mathrm{m}^{2} / \mathrm{g}\right)$ & 16.29 & 19.94 & 25.05 \\
BET surface area $\left(\mathrm{m}^{2} / \mathrm{g}\right)$ & 17.99 & 21.16 & 26.77 \\
Langmuir surface area $\left(\mathrm{m}^{2} / \mathrm{g}\right)$ & 91.16 & 72.21 & 111.95 \\
t-plot external surface area $\left(\mathrm{m}^{2} / \mathrm{g}\right)$ & 22.05 & 24.24 & 30.52 \\
Desorption cumulative volume of pores $\left(\mathrm{cm}^{3} / \mathrm{g}\right)$ & 0.047 & 0.046 & 0.070 \\
\hline
\end{tabular}
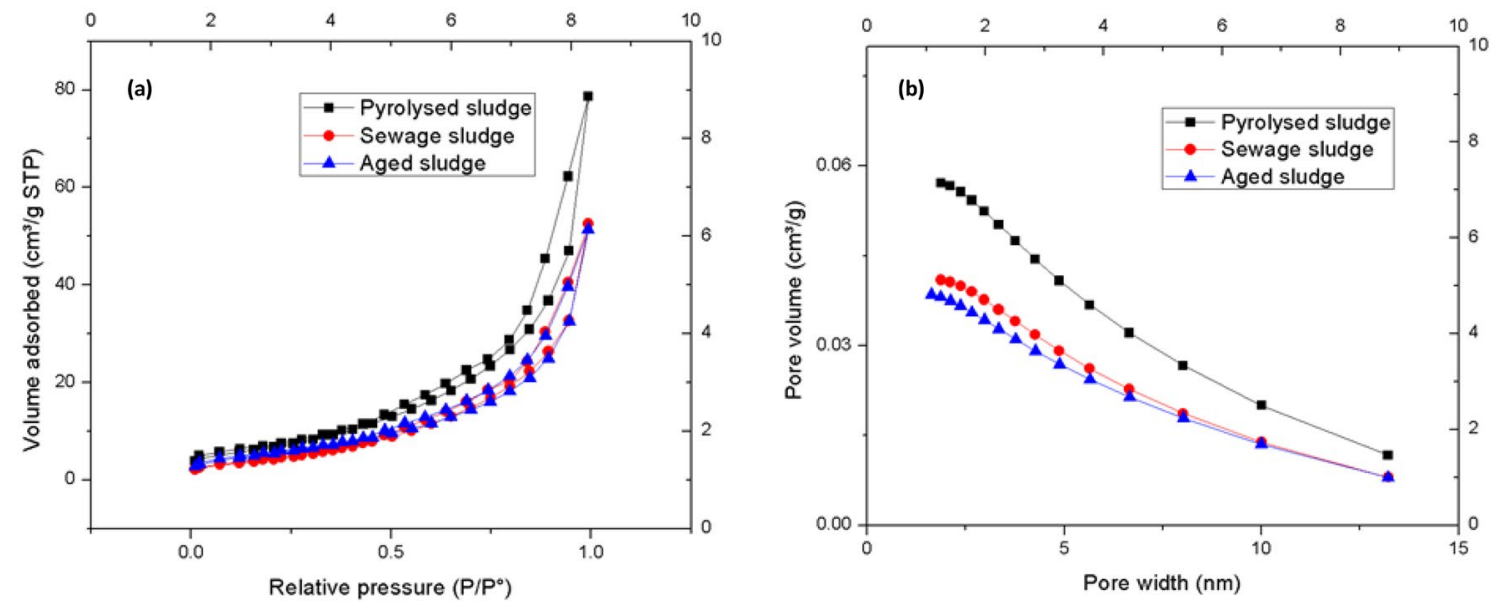

Fig. 1 Nitrogen adsorption-desorption isotherms (a) and pore size distribution plot (b) for sewage sludge, pyrolysed sludge (BC500)

temperature had a relatively larger BET surface area above $110.10 \mathrm{~m}^{2} / \mathrm{g}$. In addition, Agrafioti et al. [59] also reported a larger BET surface area $\left(90.0 \mathrm{~m}^{2} / \mathrm{g}\right)$ for sewage sludgederived biochar obtained at $500{ }^{\circ} \mathrm{C}$. High surface areas and pores are known to support pollutant sorption and modification of soil chemistry as well as microbial communities [53]. In addition, according to a report by Hale et al. [60], aging reduced sorption of pyrene, implying that the sorption process operates at a sub-particle level. Therefore, pyrolysed sludge (biochar) is expected to provide better sorption of PAHs than the non-pyrolysed sewage sludge.

The adsorption isotherm curves (Fig. 1a) showed hysteresis in the relative pressure $\left(P / P^{\circ}\right)$ range from 0.5 to 0.9 . This indicated that their structures were uniform mesopores [61]. In addition, the shapes of the adsorption isotherms (Fig. 1a) correspond to Type IV based on IUPAC classifications [62]. This, according to the classification, implies that capillary condensation is accompanied by hysteresis in the mesopores of the materials [63]. The isotherm profiles indicated that more pores exist in the pyrolysed sludge than the raw sludge and aged sample. The distribution of the micropores volume is shown in Fig. 1b. Similar pore size distribution is observed between the raw, aged and pyrolysed sludge centred at $2.5 \mathrm{~nm}$ (pore width). However, a higher volume of pores was achieved in pyrolysed sludge compared to non-pyrolysed samples. Pore accessibility and water retention ability are also considered as critical influencing factors that determine pollutants degradation [53]. The present study revealed the increase in pore size and number in the derived ash catalyst or biochar and is a pointer to its potential for enhanced degradation of organic contaminants by indigenous microbial communities.

The results of the scanning electron microscopy (SEM) of the fresh and pyrolysed sludge samples are presented in Fig. 2. The results reveal varying surface morphologies for the pyrolysed and unpyrolysed samples. Functional group characterisation of the pyrolysed sludge samples, humus sediment, and the mixture at different temperatures are depicted in the FTIR spectra presented in Fig. 3. The surface of the pyrolysed sludge at $500^{\circ} \mathrm{C}$ was rough and heterogeneous with highly porous structures. This further confirmed the findings of the adsorption isotherms results indicating that the prepared biochar is a mesoporous material with a higher surface area with internal pores compared to raw sludge. The pore structure is said to be an important property for initial sorption and degradation of organic pollutants such as PAHs [53]. 

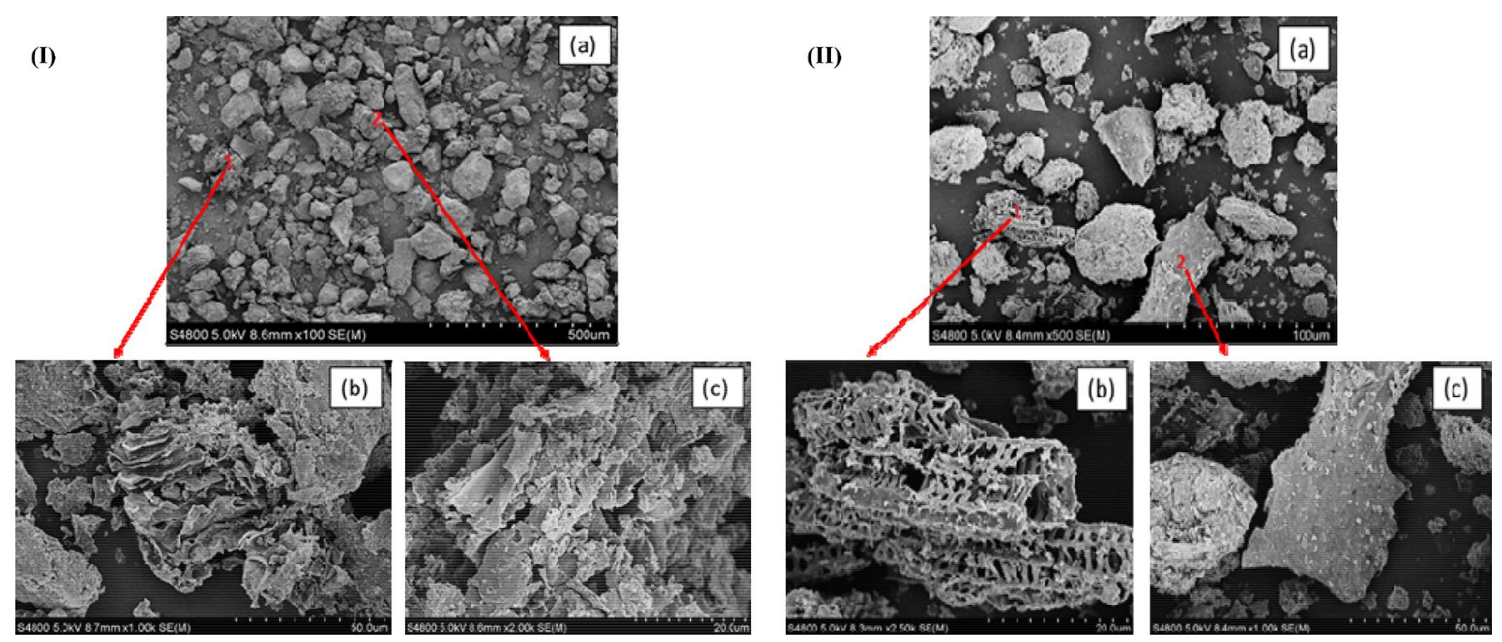

Fig. 2 (I) Surface morphology of the fresh sludge: (a) sewage sludge at different magnifications: (b) $50 \mu \mathrm{m}$ and (c) $20 \mu \mathrm{m}$; and (II) surface morphology of the pyrolysed sludge: (a) BC500 at different magnifications: (b) $20 \mu \mathrm{m}$ and (c) $50 \mu \mathrm{m}$

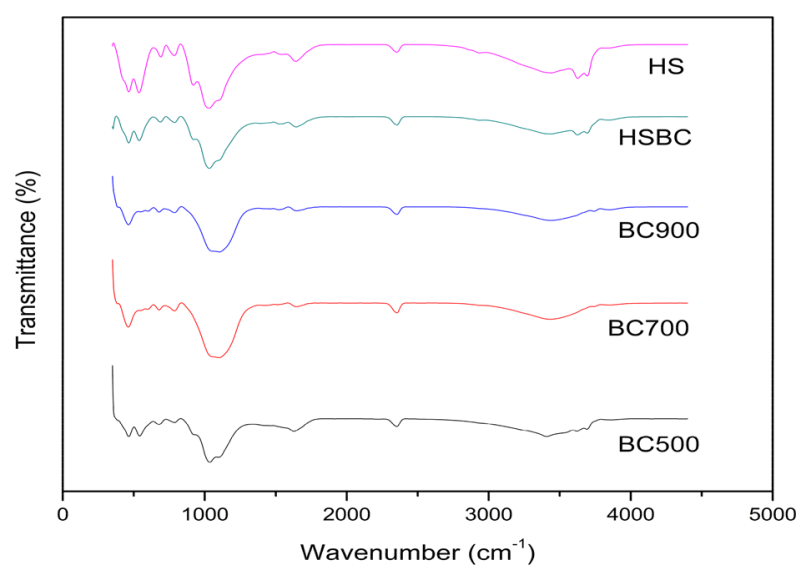

Fig. 3 Variation in functional groups in biochar/humus sediment mixtures (BC500 pyrolysed @ $500{ }^{\circ} \mathrm{C}, B C 700$ pyrolysed @ $700{ }^{\circ} \mathrm{C}$, $B C 900$ pyrolysed @ $900^{\circ} \mathrm{C}, H S B C$ biochar plus humus sediment, $H S$ humus sediment alone)

The FTIR spectra of the biochars and mixtures are illustrated in Fig. 3. Functional group assignments are presented in Table S1 (Supplementary Information). Each spectrum reflected changes in the surface functional characteristics of the biochars produced at different temperatures. The prominent peak assignments in the spectra include secondary alcohol O-H stretch $\left(\sim 3620.89 \mathrm{~cm}^{-1}\right)$, C-O stretch in secondary alcohols $\left(\sim 1102.41 \mathrm{~cm}^{-1}\right), \mathrm{N}-\mathrm{H}$ bend in aromatic amines $\left(\sim 3406.88 \mathrm{~cm}^{-1}\right)$, and $\mathrm{Ar}-\mathrm{C} \equiv \mathrm{N}$ aromatic cyanide/nitrile $\left(\sim 2352.87 \mathrm{~cm}^{-1}\right)$. Changes in the band intensities as pyrolytic temperature increased were observed. This is consistent with the study by Gai et al. [42]. Additional changes as a result of the addition of humus sediment to the biochar occurred around $3600 \mathrm{~cm}^{-1}, 2934 \mathrm{~cm}^{-1}$, and $921 \mathrm{~cm}^{-1}$. These changes are attributed to modifications of the biochar surfaces which resulted in new functionalities: $\mathrm{OH}$ stretch (phenols), aromatic $\mathrm{C}-\mathrm{H}$ stretch, and silicate ion, respectively [64]. Generally, biochars tend to contain oxygenated functional groups. However, in comparison with other studies, it was observed that the humus-biochar mixture prepared in this work contained unique functional groups. Hossain et al. [65] observed similar functional groups in a sludgederived biochar prepared at the pyrolysis temperature of $300-700{ }^{\circ} \mathrm{C}$. The authors reported the presence of $\mathrm{C}-\mathrm{O}$, $\mathrm{OH}, \mathrm{NH},-\mathrm{CH}_{3}$, and $\mathrm{NO}$ groups in the biochars. They also reported the presence of metallic compounds. Similarly, Lu et al. [66] reported the presence of aryl $C$ and carboxylic acid groups in the biochar they prepared at the pyrolysis temperature between 300 and $600{ }^{\circ} \mathrm{C}$. In addition, Jin et al. [67] reported the presence of phenolic groups and noted that peaks above $3600 \mathrm{~cm}^{-1}$ correspond to vibrations of $\mathrm{OH}$ groups in mineral materials. This suggests that prepared biochar could display both organic and inorganic properties depending on reaction conditions and environmental medium. In contrast to the present work, however, Jin et al. [67] also reported the presence of phosphorus and amide functional groups in the biochar they prepared. Variations such as these are usually attributable to biochar feedstock types and the inherent constituents.

\subsection{Microbial indicators for biodegradation of crude oil-derived PAHs}

After $24 \mathrm{~h}$, visible colonies on nutrient agar and modified mineral salt medium were enumerated and expressed as colony forming units per gram (CFU/g) of soil. The results revealed a gradual increase in the density crude oil degrading bacteria (COB) and a decrease in THBC count as the 
experiment progressed with the highest rate of increase recorded for sample $\mathrm{H}$ (Fig. 4). The initial decrease in THBC was followed by a gradual increase in the activities of the heterotrophic bacteria after 18 days. The COB/THBC ratio recorded ranged from $1.23 \times 10^{-4}$ to $6.60 \times 10^{-3}$ for control sample (A) on the first day and sample $\mathrm{H}$ after 18 days, respectively (Table $\mathrm{S} 2$ ).

Results presented in Fig. 4a, b revealed a gradual increase in the crude oil degrading bacteria and a decrease in THBC count as the day passed by with the highest rate of increase recorded for sample $\mathrm{H}$. The implication of the microbial activity in these experiments revealed that treatments with higher humus sediment content possessed greater crude oil degrading potentials. The work by Essien et al. [68] supported this observation that sediment amendments could boost microbial action on hydrocarbons.

Some previous studies have shown that biochar amended soils could lead to increased microbial activities [69]. This could be directly linked to the general modification of soil physicochemical properties such as nutrient contents and $\mathrm{pH}$. However, biochar amendments could also cause reduced microbial activities due to reduced requirements for mycorrhizal symbiosis as a result of increased nutrient and water availability to plant, extreme $\mathrm{pH}$ conditions, as well as negative effects from excess mineral elements such as certain salts and trace metals content [70]. In this study, it is possible that under high crude oil contamination, microbial activities could only be sustained with additional amendments from humus sediments since nitrogen/phosphate contents produced biochar are usually low [42]. However, the bioaugmentingbiostimulating effect of the ash biomass-humus mixture was apparent and favoured bioremediation as the indigenous populations of hydrocarbon degrading bacteria and associated degradative genes were elevated after treatments.

\subsection{Effects of biochar-humus mixtures on PAHs distribution and remediation in soil}

The results of the preliminary studies on the effects of biochar and humus substances on the distribution of PAHs in treated soils are presented in Fig. 5. The amendments that had the highest PAH suppression were those containing more of the humus sediments ( $\mathrm{E}$ and $\mathrm{H}$ ) (Fig. 5). The high attenuating ability of amendments $\mathrm{E}$ and $\mathrm{H}$ could be ascribed to enhanced biodegradation by natural
Fig. 4 Trend of crude oil degrading (a) and total heterotrophic bacterial (b) concentrations in the various samples during the 30-day study
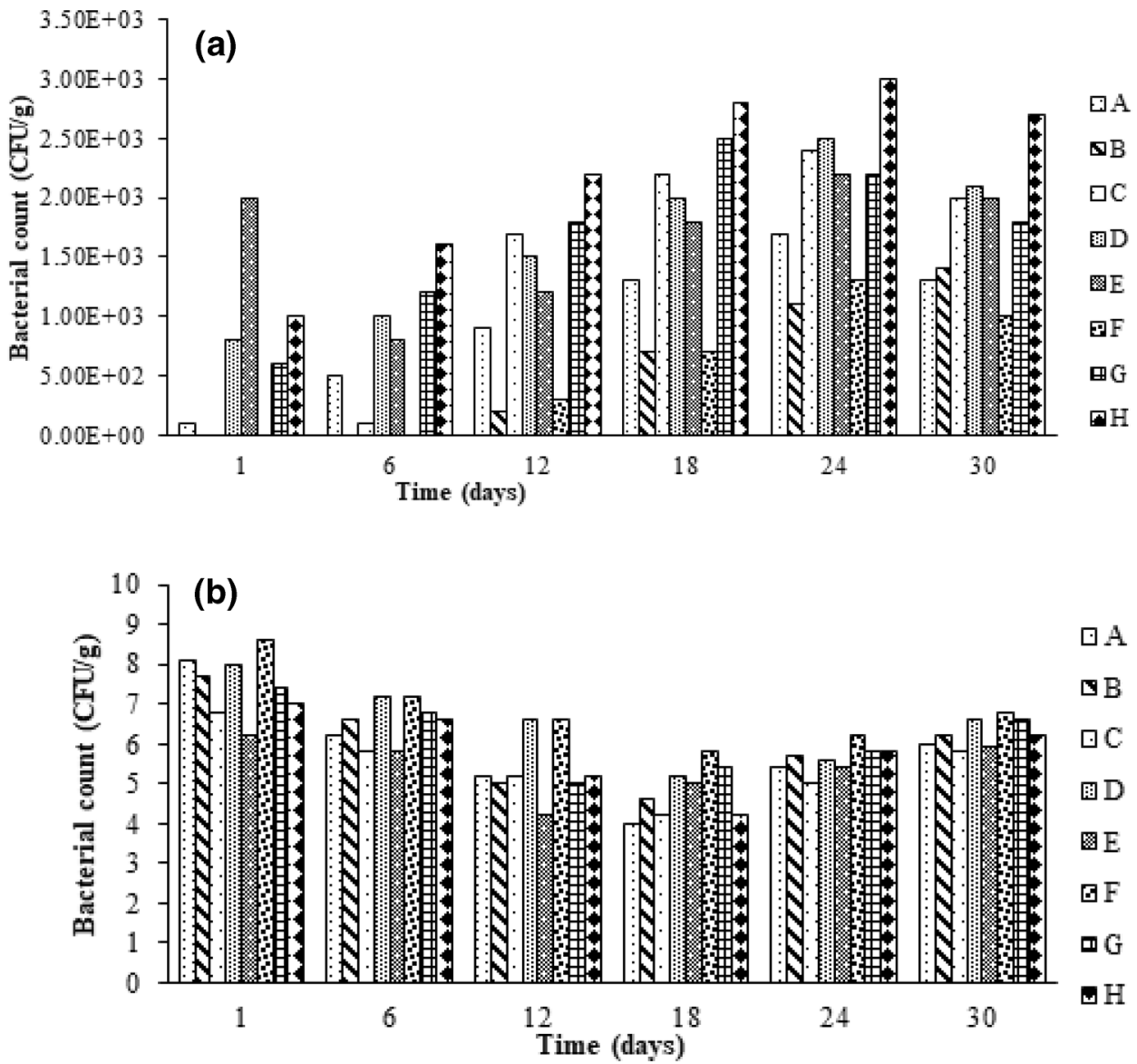


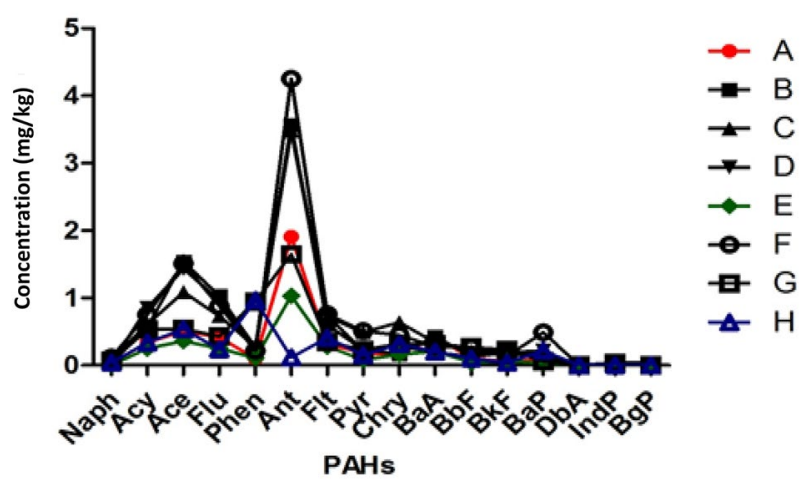

Fig. 5 Profile of PAHs in simulated soils treated with different formulations of biochar (BC500) and humus substances after 1 month

degrading bacteria from the humus sediment $[26,36]$. On the other hand, the elevated levels of PAHs in the other amendments could be attributed to poor microbial action which seems limited in biochar-dominated mixtures. Treatment B (mostly HA) performed lowest with its performance for all studied PAHs recorded at high levels after soil treatment.

In this study, it was observed that the addition of humic acid to biochar/sediment slurry mixture as part of the amendment for the treatment of crude oil-derived PAHs in soils did not prove to be very effective as against some reports by Holman et al. [36] and Ke et al. [27]. One explanation to this contrasting result could be attributed to differences in soil type. Differences in soil types will definitely exert different responses to the treatments. Derrien et al. [71] stated in their work that different sources and fractions of humic substances could affect their chemistry and functionality. Conte et al. [25] also reported that the effectiveness of $\mathrm{HA}$ as a natural surfactant for washing organic contaminants in soils was affected by soil texture and organic matter content. They suggested that the addition of HA would be more effective in soils with finer grain size (loamy-clayey). The soil used in this study is characterised as loamy-sandy $[38,40]$. Another plausible explanation is that the surface-active HA could enhance the desorption of PAHs from the biochar, thereby limiting the adsorption mechanism for PAH attenuation. Rebhun et al. [31] had observed in their study that dissolved humic substances through hydrophobic binding could reduce the sorbability of organic contaminants.

A study by Lesage et al. [72] suggested that good results could be obtained from remediation of $\mathrm{PAHs}$ in groundwater in highly controlled conditions such as buffered $\mathrm{pH} 8$, under a defined contaminant source in terms of both mass and geometry. However, such studies may be highly impracticable for field applications. Similarly, many other researchers have obtained good results under controlled conditions where only a single contaminant, such as pyrene $[26,29]$ and phenanthrene $[32,33,73]$, was considered.

The results of the present work also agree with the report by Laor and Rebhun [28], which demonstrated an evidence for non-linear binding of PAHs to dissolved $\mathrm{HAs}$ and concluded that linear partitioning or site complexation in the presence of excess available sites cannot fully describe the interactions of hydrophobic compounds with dissolved humic materials. They suggested that site-specific hydrophobic interactions at the limited interior or exterior molecular surfaces could be considered. Furthermore, when considering complex mixtures, HA-enhanced sorption/degradation has been reported to show different patterns. For example, Seibel et al. [74] observed that in the presence of microbial mixtures, $\mathrm{HA}$ increased the degradation of naphthalene but decreased that of phenanthrene. Lippold et al. [30] also reported a similar observation where the solubility of pyrene by humic acid was negated in the presence of cationic and anionic surfactants. The authors concluded that remediation measures on the basis of micellar solubilisation are not significantly affected by the presence of natural amphiphilic compounds (such as HAs).

\subsection{Effects of time and biochar pyrolysis temperature on soil characteristics and remediation}

It was observed that treatments containing mainly humic acid and/or biochar (samples B, C, D) were not as efficient as those containing mainly humus sediment and biochar (samples $\mathrm{E}$ and $\mathrm{H}$ ). The levels of total PAHs were then monitored in selected biochar treatments $(E$ and $H)$ including the contaminated soil blank (A) over a period of 1,6 , and 12 months at three intervals (Tables 5, 6 and 7). Generally, the levels of PAHs reduced over time in all the treatments.

The result reveals that the levels of PAHs reduced as time increased. In the contaminated soil without treatment, the levels of PAHs also reduced over time as well. There are many factors that could be attributed to this observation. On one hand, PAHs are semivolatile and could have undergone evaporation from the media. Therefore, time (greater than 1 month) is not considered a major influence on the efficiency of the treatments as other uncontrollable environmental factors may affect the transformation of PAHs. Talley et al. [75] also made similar observations for sediment bioslurry treatment of contaminated sediments monitored over a period of 4 months.

In comparison to the results for the control experiment (Table 5), the results presented in Tables 6 and 7 reveal that the best treatment recorded for total-PAHs were obtained after 30 days with over $70 \%$ and $40 \%$ removal 
Table 5 Influence of time on the levels of PAHs after soil treatment A (blank) $)^{\mathrm{a}}$

\begin{tabular}{llll}
\hline Compound & \multicolumn{3}{l}{$\begin{array}{l}\text { Levels after monitoring intervals } \\
\text { (mg/kg) }\end{array}$} \\
\cline { 2 - 4 } & 1 month & 6 months & 12 months \\
\hline Naphthalene (Naph) & 0.03 & 0.02 & 0.01 \\
Acenaphthylene (Acy) & 0.85 & 0.02 & 0.02 \\
Acenaphthene (Ace) & 1.43 & 0.02 & 0.02 \\
Fluorene (Flu) & 0.97 & 0.04 & 0.03 \\
Phenanthrene (Phen) & 0.23 & 0.13 & 0.18 \\
Anthracene (Ant) & 3.53 & 0.25 & 0.19 \\
Fluoranthene (Flt) & 0.74 & 0.22 & 0.02 \\
Pyrene (Pyr) & 0.21 & 0.24 & 0.05 \\
Chrysene (Chry) & 0.29 & 0.15 & 0.03 \\
Benzo(a)anthracene (BaA) & 0.19 & 0.02 & 0.02 \\
Benzo(b)fluoranthene (BbF) & 0.13 & 0.03 & 0.03 \\
Benzo(k)fluoranthene (BkF) & 0.19 & 0.02 & 0.03 \\
Benzo(a)pyrene (BaP) & 0.22 & 0.01 & 0.02 \\
Dibenzo(a,h)anthracene (DbA) & $\mathrm{BDL}$ & 0.05 & 0.06 \\
Indeno(1,2,3-cd)pyrene (IndP) & $\mathrm{BDL}$ & 0.06 & 0.10 \\
Benzo(g,h,i)perylene (BgP) & $\mathrm{BDL}$ & 0.03 & 0.02 \\
I16USEPA-PAHs & 9.01 & 1.31 & 0.83 \\
\hline
\end{tabular}

${ }^{\text {a }}$ Treatment $\mathrm{A}$ is blank which contains only the soil and spiked crude oil

Table 6 Influence of time on the levels of PAHs after soil treatment $\mathrm{E}^{\mathrm{a}}$

\begin{tabular}{llll}
\hline Compound & \multicolumn{3}{l}{$\begin{array}{l}\text { Levels after monitoring intervals } \\
\text { (mg/kg) }\end{array}$} \\
\cline { 2 - 4 } & 1 month & 6 months & 12 months \\
\hline Naphthalene (Naph) & $\mathrm{BDL}$ & 0.02 & $\mathrm{BDL}$ \\
Acenaphthylene (Acy) & 0.25 & 0.02 & $\mathrm{BDL}$ \\
Acenaphthene (Ace) & 0.36 & 0.02 & $\mathrm{BDL}$ \\
Fluorene (Flu) & 0.25 & 0.0 & 0.06 \\
Phenanthrene (Phen) & 0.11 & 0.09 & 0.05 \\
Anthracene (Ant) & 1.03 & 0.10 & 0.12 \\
Fluoranthene (Flt) & 0.28 & 0.20 & $\mathrm{BDL}$ \\
Pyrene (Pyr) & 0.08 & 0.15 & 0.04 \\
Chrysene (Chry) & 0.16 & 0.10 & 0.08 \\
Benzo(a)anthracene (BaA) & 0.21 & 0.02 & $\mathrm{BDL}$ \\
Benzo(b)fluoranthene (BbF) & 0.04 & 0.03 & 0.02 \\
Benzo(k)fluoranthene (BkF) & 0.07 & 0.02 & 0.06 \\
Benzo(a)pyrene (BaP) & 0.03 & 0.06 & $\mathrm{BDL}$ \\
Dibenzo(a,h)anthracene (DbA) & $\mathrm{BDL}$ & $\mathrm{BDL}$ & $\mathrm{BDL}$ \\
Indeno(1,2,3-cd)pyrene (IndP) & $\mathrm{BDL}$ & $\mathrm{BDL}$ & $\mathrm{BDL}$ \\
Benzo(g,h,i)perylene (BgP) & $\mathrm{BDL}$ & $\mathrm{BDL}$ & $\mathrm{BDL}$ \\
I16USEPA-PAHs & 2.87 & 0.83 & 4.43 \\
\hline
\end{tabular}

${ }^{a}$ Treatment $\mathrm{E}$ is a sample which contains the soil with spiked crude oil, humic acid, and humus sediment
Table 7 Influence of time on the levels of PAHs after soil treatment $\mathrm{H}^{\mathrm{a}}$

\begin{tabular}{llll}
\hline Compound & \multicolumn{3}{l}{$\begin{array}{l}\text { Levels after monitoring intervals } \\
(\mathrm{mg} / \mathrm{kg})\end{array}$} \\
\cline { 2 - 4 } & 1 month & 6 months & 12 months \\
\hline Naphthalene (Naph) & 0.04 & 0.02 & 0.01 \\
Acenaphthylene (Acy) & 0.34 & 0.03 & $\mathrm{BDL}$ \\
Acenaphthene (Ace) & 0.54 & 0.05 & 0.01 \\
Fluorene (Flu) & 0.24 & 0.07 & 0.01 \\
Phenanthrene (Phen) & 0.97 & 0.22 & 0.01 \\
Anthracene (Ant) & 0.12 & 0.55 & 0.03 \\
Fluoranthene (Flt) & 0.41 & 0.19 & 0.03 \\
Pyrene (Pyr) & 0.15 & 0.21 & 0.03 \\
Chrysene (Chry) & 0.32 & 0.08 & 0.01 \\
Benzo(a)anthracene (BaA) & 0.2 & 0.04 & 0.01 \\
Benzo(b)fluoranthene (BbF) & 0.1 & 0.05 & 0.01 \\
Benzo(k)fluoranthene (BkF) & 0.04 & 0.03 & 0.01 \\
Benzo(a)pyrene (BaP) & 0.22 & 0.04 & 0.01 \\
Dibenzo(a,h)anthracene (DbA) & $\mathrm{BDL}$ & 0.08 & 0.01 \\
Indeno(1,2,3-cd)pyrene (IndP) & $\mathrm{BDL}$ & 0.12 & 0.03 \\
Benzo(g,h,i)perylene (BgP) & $\mathrm{BDL}$ & 0.07 & 0.01 \\
I16USEPA-PAHs & 3.69 & 1.85 & 0.23 \\
\hline
\end{tabular}

${ }^{a}$ Treatment $\mathrm{H}$ is a sample which contains the soil with spiked crude oil, humus sediment, and biochar (BC500); $B D L$ below detectable limits

achieved in treatments $\mathrm{E}$ and $\mathrm{H}$, respectively. There was no specific trend observed after 6 months as either PAH levels remained unchanged or were higher. It is difficult to explain the challenges because crude oil is a very complex mixture which can exert unpredicted outcomes. Another explanation may be that 16 total PAHs were considered. With changes in the reactions and interactions in the system, it is unclear how each component performed or affected each other. Furthermore, it may be possible that PAH degradation by microbial action from humus sediment diminished at the complete consumption of available nutrients provided by the biochar (BC500). Biochars produced at higher pyrolysis temperature were not tried because at higher temperatures they contain little nutrients, especially NP [42], and may have acted more as a catalyst than a nutrient source. Nevertheless, it can be deduced from the results that under excess crude oil inoculation, the treatment of the simulated soils under different treatments performed best at the initial 30 days.

\subsection{Effects of sludge pyrolysis temperature on the levels of PAHs of treated soil}

After the treatment of contaminated soil with biochars obtained at different pyrolysis temperatures, we analysed 
the treatments after 1 month for PAHs and the results are presented in Table 3. Interestingly, total PAH levels in soil treated with $\mathrm{BC} 900$-derived mixture was the highest $(0.94 \mathrm{mg} / \mathrm{kg})$, followed by BC500 $(0.51 \mathrm{mg} / \mathrm{kg})$ and BC700 $(0.31 \mathrm{mg} / \mathrm{kg})$. The result seemed not to produce a consistent pattern. On one hand, the high levels of PAHs in BC900 treatment may be due to the formation of high molecular weight (HMW) PAHs which are known to form at high temperatures [76]. It would therefore imply that the application of biochars derived from pyrolysis at a temperature above $700{ }^{\circ} \mathrm{C}$ would not be recommended as they may become sources for HMW PAHs. Similarly, Anyika et al. [53] does not recommend he application of biochars produced at temperatures higher than $850^{\circ} \mathrm{C}$.

\subsection{Levels of PAHs in relation to crude oil contamination volume and treatment dosage}

Further studies to determine optimum conditions for the treatment of contaminated soil were carried out. These involved determination of the levels of $\mathrm{PAHs}$ in varied composition of $\mathrm{BC} 700$ (the most suitable from the previous stage) and humus sediment as well as different volumes of crude oil used. The results of these experiments are presented in Tables 8 and 9. When the contaminated soil was treated with different amounts of biochar/humus sediment mixture (HSBC), it was observed that the highest levels of total PAHs $(19.72 \mathrm{mg} / \mathrm{kg})$ were recorded in the mixture containing the highest amount of HSBC $(60 \mathrm{~g})$. This was followed by $20 \mathrm{~g} \mathrm{HSBC}(11.36 \mathrm{mg} / \mathrm{kg})$, $25 \mathrm{~g} \mathrm{HSBC}(6.72 \mathrm{mg} / \mathrm{kg}), 35 \mathrm{~g} \mathrm{HSBC}(6.12 \mathrm{mg} / \mathrm{kg})$, and $15 \mathrm{~g}$ HSBC $(5.17 \mathrm{mg} / \mathrm{kg})$. There was no significant correlation observed between the levels of PAHs and the amount of HSBC applied. This observation could be due to the fact that PAH degradation in the environment is more responsive to soil microbial communities. This happens in a situation where microbes are able to sorb on the biochar surface, reducing their leachability in soils [70]. In other words, sorption activity which is one of the primary mechanisms of biochar action on PAHs in soil may reduce, leading to less performance irrespective of the amount applied. Furthermore, Ogbonnaya and Semple [77] observed that biochar sorption of organic contaminants is also governed by several other factors such as feedstock type, production process, sorbate concentration and physical properties, aging period, and soil properties. The levels of PAHs were monitored in treated soils with varied crude contamination volumes (Table 9). After treatment, the highest contamination level $(500 \mathrm{~mL}$ in $0.8 \mathrm{~kg}$ of soil) still contained high residues of total PAHs recorded at $24.97 \mathrm{mg} / \mathrm{kg}$. This was followed by $300 \mathrm{~mL}$ of crude oil $(26.62 \mathrm{mg} / \mathrm{kg}), 120 \mathrm{~mL}$ of crude oil ( $20.56 \mathrm{mg} / \mathrm{kg}), 200 \mathrm{~mL}$ of crude oil $(7.41 \mathrm{mg} /$ $\mathrm{kg})$, and $250 \mathrm{~mL}(4.76 \mathrm{mg} / \mathrm{kg})$. No particular pattern was
Table 8 Effects of biochar/sediment mixture concentration on the levels of PAHs $(\mathrm{mg} / \mathrm{kg})$ in treated soils*

\begin{tabular}{llllll}
\hline Compound & \multicolumn{5}{l}{$\begin{array}{l}\text { Concentration of biochar/humus } \\
\text { sediment mixture }\end{array}$} \\
\cline { 2 - 6 } & $15 \mathrm{~g}^{\mathrm{a}}$ & $20 \mathrm{~g}^{\mathrm{b}}$ & $25 \mathrm{~g}^{\mathrm{c}}$ & $35 \mathrm{~g}^{\mathrm{d}}$ & $60 \mathrm{~g}^{\mathrm{e}}$ \\
\hline Naphthalene (Naph) & 1.39 & 3.58 & 2.32 & 1.42 & 10.23 \\
Acenaphthylene (Acy) & 0.15 & 0.53 & 0.19 & 0.18 & 0.78 \\
Acenaphthene (Ace) & 0.05 & 0.69 & 0.30 & 0.26 & 0.85 \\
Fluorene (Flu) & 0.44 & 1.36 & 0.55 & 0.52 & 1.53 \\
Phenanthrene (Phen) & 0.98 & 0.53 & 1.12 & 1.01 & 2.44 \\
Anthracene (Ant) & 1.12 & 3.31 & 1.29 & 1.54 & 2.77 \\
Fluoranthene (Flt) & 0.10 & 0.32 & 0.04 & 0.06 & 0.14 \\
Pyrene (Pyr) & 0.16 & 0.10 & 0.09 & 0.13 & 0.16 \\
Chrysene (Chry) & 0.10 & 0.28 & 0.12 & 0.13 & 0.30 \\
Benzo(a)anthracene (BaA) & 0.14 & 0.34 & 0.14 & 0.12 & 0.14 \\
Benzo(b)fluoranthene (BbF) & 0.20 & 0.10 & 0.26 & 0.28 & 0.15 \\
Benzo(k)fluoranthene (BkF) & 0.11 & 0.06 & 0.14 & 0.16 & 0.09 \\
Benzo(a)pyrene (BaP) & 0.11 & 0.11 & 0.06 & 0.23 & 0.06 \\
Dibenzo(a,h)anthracene (DbA) & 0.03 & 0.02 & 0.03 & 0.03 & 0.01 \\
Indeno(1,2,3-cd)pyrene (IndP) & 0.06 & 0.02 & 0.04 & 0.04 & 0.06 \\
Benzo(g,h,i)perylene (BgP) & 0.03 & 0.01 & 0.03 & 0.01 & 0.01 \\
I16USEPA-PAHs & 5.17 & 11.36 & 6.72 & 6.12 & 19.72 \\
\hline & & & &
\end{tabular}

*Other experimental details: $800 \mathrm{~g}$ soil; $120 \mathrm{~mL}$ crude oil; Biochar obtained at $700{ }^{\circ} \mathrm{C}$ (i.e. BC700) was used

${ }^{\mathrm{a}} 5 \mathrm{~g}$ of biochar and $10 \mathrm{~g}$ of humus sediment

${ }^{\mathrm{b}} 10 \mathrm{~g}$ of biochar and $10 \mathrm{~g}$ of humus sediment

' $15 \mathrm{~g}$ of biochar and $10 \mathrm{~g}$ of humus sediment

${ }^{\mathrm{d}} 25 \mathrm{~g}$ of biochar and $10 \mathrm{~g}$ of humus sediment

e $50 \mathrm{~g}$ of biochar and $10 \mathrm{~g}$ of humus sediment

observed from the results, and there was no significant correlation between the level of contamination and the levels of PAHs.

\section{Conclusion}

The present study evaluated the effects of humus sediment slurry on PAH distribution in sewage sludgederived biochar amended tropical ultisol contaminated with crude oil. Based on the results obtained, this study revealed that biochar derived through sewage sludge valorisation by means of pyrolysis combined with humus sediment slurry can serve as useful remediant for the clean-up of soils contaminated with crude oil-derived PAHs. The efficiency of the prepared co-mixture was highly influenced by the level of crude oil contamination. Optimum conditions were obtained after initial 1 month of application of the prepared biochar/humus sediment mixture. The results also revealed that the co-mixture 
Table 9 Effects of crude oil amount on the levels of PAHs $(\mathrm{mg} / \mathrm{kg}$ ) after soil treatment*

\begin{tabular}{|c|c|c|c|c|c|}
\hline \multirow[t]{2}{*}{ Compound } & \multicolumn{5}{|c|}{$\begin{array}{l}\text { Level of contamination (volume of } \\
\text { crude oil spiked)** }\end{array}$} \\
\hline & $120 \mathrm{~mL}^{\mathrm{a}}$ & $200 \mathrm{~mL}^{\mathrm{b}}$ & $250^{c}$ & $300^{d}$ & $500^{e}$ \\
\hline Naphthalene (Naph) & 7.71 & 1.90 & 0.80 & 17.28 & 10.65 \\
\hline Acenaphthylene (Acy) & 0.92 & 0.26 & 0.22 & 0.52 & 0.76 \\
\hline Acenaphthene (Ace) & 0.85 & 0.42 & 0.30 & 1.07 & 0.87 \\
\hline Fluorene (Flu) & 1.64 & 0.79 & 0.61 & 1.06 & 1.37 \\
\hline Phenanthrene (Phen) & 3.72 & 1.50 & 0.91 & 2.17 & 4.35 \\
\hline Anthracene (Ant) & 4.09 & 1.67 & 1.06 & 2.48 & 4.84 \\
\hline Fluoranthene (Flt) & 0.16 & 0.06 & 0.04 & 0.08 & 0.15 \\
\hline Pyrene (Pyr) & 0.18 & 0.02 & 0.11 & 0.27 & 0.26 \\
\hline Chrysene (Chry) & 0.31 & 0.19 & 0.17 & 0.22 & 0.13 \\
\hline Benzo(a)anthracene (BaA) & 0.17 & 0.14 & 0.02 & 0.33 & 0.44 \\
\hline $\begin{array}{l}\text { Benzo(b)fluoranthene } \\
\text { (BbF) }\end{array}$ & 0.36 & 0.09 & 0.09 & 0.56 & 0.8 \\
\hline $\begin{array}{l}\text { Benzo(k)fluoranthene } \\
\text { (BkF) }\end{array}$ & 0.19 & 0.09 & 0.11 & 0.33 & 0.12 \\
\hline Benzo(a)pyrene (BaP) & 0.06 & 0.22 & 0.02 & 0.22 & 0.16 \\
\hline $\begin{array}{l}\text { Dibenzo(a,h)anthracene } \\
\text { (DbA) }\end{array}$ & 0.01 & 0.01 & 0.10 & 0.01 & 0.05 \\
\hline $\begin{array}{l}\text { Indeno(1,2,3-cd)pyrene } \\
\quad(\text { IndP) }\end{array}$ & 0.17 & 0.02 & 0.20 & $\mathrm{BDL}$ & 0.01 \\
\hline Benzo(g,h,i)perylene (BgP) & 0.02 & 0.03 & BDL & 0.02 & 0.01 \\
\hline$\Sigma 16$ USEPA-PAHs & 20.56 & 7.41 & 4.76 & 26.62 & 24.97 \\
\hline
\end{tabular}

*Other experimental details: $800 \mathrm{~g}$ soil; $120 \mathrm{~mL}$ crude oil; Biochar obtained at $700{ }^{\circ} \mathrm{C}$ (i.e. BC700) was used

**Volume of crude oil spiked was varied as HSBC amount was kept constant at $50 \mathrm{~g}$ and $0.80 \mathrm{~kg}$ of soil

${ }^{\mathrm{a}} 5 \mathrm{~g}$ of biochar and $10 \mathrm{~g}$ of humus sediment

${ }^{\mathrm{b}} 10 \mathrm{~g}$ of biochar and $10 \mathrm{~g}$ of humus sediment

' $15 \mathrm{~g}$ of biochar and $10 \mathrm{~g}$ of humus sediment

${ }^{\mathrm{d}} 25 \mathrm{~g}$ of biochar and $10 \mathrm{~g}$ of humus sediment

${ }^{\mathrm{e}} 50 \mathrm{~g}$ of biochar and $10 \mathrm{~g}$ of humus sediment

encouraged microbial proliferation and activities thus providing favourable conditions for PAH biodegradation to occur.

Acknowledgements We are grateful to Dr Ubong J. Etim of State Key Laboratory of Heavy Oil Processing, China University of Petroleum, Huadong, Qingdao, P.R. China for some of the instrumental analyses. Dr Nnanake-Abasi O. Offiong is grateful to Shell Petroleum Development Company of Nigeria (SPDC) for Postgraduate Research Internship position and financial support for this project. We thank the Editor and the anonymous reviewers whose comments helped improve the quality of the original manuscript.

\section{Compliance with ethical standards}

Conflict of interest The authors declare that they have no known competing financial interests or personal relationships that could have appeared to influence the work reported in this paper.

\section{References}

1. Beecher N (2008) Overview, pp. 15-84. In: DeBlanc RJ, Matthews P, Richard RP (eds) Global atlas of excreta, wastewater sludge, and biosolids management: moving forward the sustainable and welcome uses of a global resource. United Nations Human Settlement Programme, Nairobi, Kenya, p 608

2. Khan S, Chao C, Waqas M, Arp HPH, Zhu Y (2013) Sewage sludge biochar influence upon rice (Oryza sativa $\mathrm{L}$ ) yield, metal bioaccumulation and greenhouse gas emissions from acidic paddy soil. Environ Sci Technol 47(15):8624-8632

3. Luostarinen S, Luste S, Sillanpaa M (2009) Increased biogas production at wastewater treatment plants through co-digestion of sewage sludge with grease trap sludge from a meat processing plant. Bioresour Technol 100(1):79-85

4. Monteiro SN, Alexandre J, Margem JI, Sánchez R, Vieira CMF (2008) Incorporation of sludge waste from water treatment plant into red ceramic. Constr Build Mater 22(6):1281-1287

5. Sun R, Xing D, Jia J, Liu Q, Zhou A, Bai S, Ren N (2014) Optimization of high-solid waste activated sludge concentration for hydrogen production in microbial electrolysis cells and microbial community diversity analysis. Int J Hydrogen Energy 39(35):19912-19920

6. Smith KM, Fowler GD, Pullket S, Graham NJD (2009) Sewage sludge-based adsorbents: a review of their production, properties and use in water treatment applications. Water Res 43(10):2569-2594

7. Fytili D, Zabaniotou A (2008) Utilization of sewage sludge in EU application of old and new methods - a review. Renew Sustain Energy Rev 12:116-140

8. Mountouris A, Voutsas E, Tassios D (2008) Plasma gasification of sewage sludge: Process development and energy optimization. Energy Convers Manag 49(8):2264-2271

9. Murakami T, Suzuki Y, Nagasawa H, Yamamoto T, Koseki T (2009) Combustion characteristics of sewage sludge in an incineration plant for energy recovery. Fuel Process Technol 90(6):778-783

10. Hornick SB, Sikora LJ, Sterret SB, Murray JJ, Millner PD, Burge WD, Colacicco D, Parr JF, Chaney RL, Willson GB (1984) Utilization of sewage sludge compost as a soil conditioner and fertilizer for agriculture. Information Bulletin No. 464, United States Department of Agriculture (USDA). US Government Printing Office, Washington, DC, $\mathrm{p} 32$

11. Rozada F, Otero M, Morán A, García Al (2005) Activated carbons from sewage sludge and discarded tyres: production and optimization. J Hazard Mater 124:181-191

12. Waqas M, Li G, Khan S, Shamshad I, Reid BJ, Qamar Z, Chao C (2015) Application of sewage sludge and sewage sludge biochar to reduce polycyclic aromatic hydrocarbons (PAH) and potentially toxic elements (PTE) accumulation in tomato. Environ Sci Pollut Res 22(16):12114-12123

13. Qin G, Gong D, Fan MY (2013) Bioremediation of petroleumcontaminated soil by biostimulation amended with biochar. Int Biodeterior Biodegrad 85:150-155

14. Zhang $X$, Wang H, He L, Lu K, Sarmah A, Li J, Bolan NS, Pei J, Huang $\mathrm{H}$ (2013) Using biochar for remediation of soils contaminated with heavy metals and organic pollutants. Environ Sci Pollut Res 20(12):8472-8483

15. Hale SE, Elmquist M, Brändli R, Hartnik T, Jakob L, Henriksen $T$ et al (2012) Activated carbon amendment to sequester PAHs in contaminated soil: a lysimeter field trial. Chemosphere 87(2):177-184

16. Sharma A, Singh SB, Sharma R, Chaudhary P, Pandey AK, Ansari $R$ et al (2016) Enhanced biodegradation of PAHs by microbial consortium with different amendment and their fate in in-situ condition. J Environ Manage 181:728-736 
17. Włóka D, Placek A, Rorat A, Smol M, Kacprzak M (2017) The evaluation of polycyclic aromatic hydrocarbons (PAHs) biodegradation kinetics in soil amended with organic fertilizers and bulking agents. Ecotoxicol Environ Saf 145(July):161-168

18. Chen W, Meng J, Han X, Lan Y, Zhang W (2019) Past, present, and future of biochar. Biochar 1(1):75-87

19. Ramtahal G, Umaharan P, Hanuman A, Davis C, Ali L (2019) The effectiveness of soil amendments, biochar and lime, in mitigating cadmium bioaccumulation in Theobroma cacao $L$. Sci Total Environ 693:133563. https://doi.org/10.1016/j.scito tenv.2019.07.369

20. Xiao X, Chen B, Chen Z, Zhu L, Schnoor JL (2018) Insight into multiple and multilevel structures of biochars and their potential environmental applications: a critical review. Environ Sci Technol 52(9):5027-5047

21. Xie T, Reddy KR, Wang C, Yargicoglu E, Spokas K (2015) Characteristics and applications of biochar for environmental remediation: a review. Crit Rev Environ Sci Technol 45:939-969

22. Xu C, Nasrollahzadeh M, Selva M, Issaabadi Z, Luque R (2019) Waste-to-wealth: biowaste valorization into valuable bio(nano) materials. Chem Soc Rev 48(18):4791-4822

23. Gunarathne V, Ashiq A, Ramanayaka S, Wijekoon P, Vithanage M (2019) Biochar from municipal solid waste for resource recovery and pollution remediation. Environ Chem Lett 17(3):1225-1235

24. Wu S, He H, Inthapanya X, Yang C, Lu L, Zeng G, Han Z (2017) Role of biochar on composting of organic wastes and remediation of contaminated soils-a review. Environ Sci Pollut Res 24(20):16560-16577

25. Conte P, Agretto A, Spaccini R, Piccolo A (2005) Soil remediation: humic acids as natural surfactants in the washings of highly contaminated soils. Environ Pollut 135:515-522

26. Haderlein A, Legros R, Ramsay B (2001) Enhancing pyrene mineralization in contaminated soil by the addition of humic acids or composted contaminated soil. Appl Microbiol Biotechnol 56:555-559

27. Ke L, Bao W, Chen L, Wong YS, Tam NFY (2009) Effects of humic acid on solubility and biodegradation of polycyclic aromatic hydrocarbons in liquid media and mangrove sediment slurries. Chemosphere 76:1102-1108

28. Laor Y, Rebhun M (2002) Evidence for nonlinear binding of PAHs to dissolved humic acids. Environ Sci Technol 36:955-961

29. Liang Y, Britt DW, McLean JE, Sorensen DL, Sims RC (2007) Humic acid effect on pyrene degradation: finding an optimal range for pyrene solubility and mineralization enhancement. Appl Microbiol Biotechnol 74:1368-1375

30. Lippold H, Gottschalch U, Kupsch H (2008) Joint influence of surfactants and humic matter on PAH solubility. Are mixed micelles formed? Chemosphere 70:1979-1986

31. Rebhun M, de Smedt F, Rwetabula J (1996) Dissolved humic substances for remediation of sites contaminated by organic pollutants: binding-desorption model predictions. Water Res 30(9):2027-2038

32. Wen B, Zhang JJ, Zhang SZ, Shan XQ, Khan SU, Xing B (2007) Phenanthrene sorption to soil humic acid and different humic fractions. Environ Sci Technol 41(9):3165-3171

33. Yang K, Xing B (2009) Sorption of phenanthrene by humic acid-coated nanosized $\mathrm{TiO}_{2}$ and $\mathrm{ZnO}$. Environ Sci Technol 43(6):1845-1851

34. Inam E, Ebong G, Offiong N-A (2018) Start-up case study on building green chemistry laboratories in University of Uyo, Nigeria. Sustain Chem Pharm 10:56-59. https://doi.org/10.1016/j. scp.2018.09.003

35. Offiong NO, Inam EJ, Etuk HS, Essien JP (2019) Current status and challenges of remediating petroleum-derived PAHs in soils: Nigeria as a case study for developing countries. Remed J 30(1):65-75. https://doi.org/10.1002/rem.21630
36. Holman HYN, Nieman K, Sorensen DL, Miller CD, Martin MC, Borch T, McKinney WR, Sims RC (2002) Catalysis of PAH biodegradation by humic acid shown in synchrotron infrared studies. Environm Sci Technol 36(6):1276-1280

37. Inam E, Etuk I, Offiong N, Kim KW, Kang SY, Essien J (2018) Distribution and ecological risks of polycyclic aromatic hydrocarbons (PAHs) in sediments of different tropical water ecosystems in Niger Delta, Nigeria. Environ Earth Sci 77:216. https:// doi.org/10.1007/s12665-018-7396-4

38. Essien JP, Udosen ED (2000) Distribution of actinomycetes in oil contaminated ultisols of the Niger Delta (Nigeria). J Environ Sci 12(3):296-302

39. John RC, Itah AY, Essien JP, Ikpe DI (2011) Fate of nitrogenfixing bacteria in crude oil contaminated wetland ultisol. Bull Environ Contamin Toxicol 87:343-353

40. Udosen ED, Essien JP, Ubom RM (2001) Bioamendment of petroleum contaminated ultisol: effect on soil content, heavy metals and $\mathrm{pH}$ of tropical soil. J Environ Sci 13(1):92-98

41. Inam E, Udo OO, Edet JB, Etim UJ, Offiong NO (2018) Adsorption of methylene blue from aqueous solution by humic acid extracted from freshwater humus. J Mater Environ Sci 9(4):1324-1334

42. Gai X, Wang H, Liu J, Zhai L, Liu S, Ren T, Liu H (2014) Effects of feedstock and pyrolysis temperature on biochar adsorption of ammonium and nitrate. PLoS One 9(12):1-19

43. Zielinska A, Oleszczuk P (2016) Attenuation of phenanthrene and pyrene adsorption by sewage sludge-derived biochar in biochar-amended soils. Environ Sci Pollut Res 23(21):21822-21832

44. Li GL, Lang YH, Gao MS, Yang W, Peng P, Wang XM (2014) Carcinogenic and mutagenic potencies for different PAHs sources in coastal sediments of Shandong Peninsula. Mar Pollut Bull 84:418-423

45. Lancaster VA, Keller-McNulty S (1998) A review of composite sampling methods. J Am Stat Assoc 93(443):1216-1230. https ://doi.org/10.1080/01621459.1998.10473781

46. Lawrence PG, Roper W, Morris TF, Guillard K (2020) Guiding soil sampling strategies using classical and spatial statistics: a review. Agron J 112(1):493-510. https://doi.org/10.1002/ agj2.20048

47. Lovison G, Gore SD, Patil GP (1994) Design and analysis of composite sampling procedures: a review. In: Patil GP, Rao CR (eds) Handbook of statistics, vol 12. Elsevier, New York, pp 103-166. https://doi.org/10.1016/S0169-7161(05)80006-9

48. United States Environmental Protection Agency (USEPA) (1995) EPA observational economy series, vol 1. Composite sampling. EPA-230-R-95-005. United States Environmental Protection Agency, Washington, DC. https://www.epa.gov/ sites/production/files/2016-03/documents/comp-samp.pdf

49. Cao Y, Yang B, Song Z, Wang H, He F, Han X (2016) Wheat straw biochar amendments on the removal of polycyclic aromatic hydrocarbons (PAHs) in contaminated soil. Ecotoxicol Environ Saf 130:248-255

50. Danish Environmental Protection Agency (2000) Guidance regarding advice of inhabitants of slightly contaminated soil (in Danish). Danish EPA, Office of soil Contamination, Copenhagen, 75 pp. http://www.mst.dk/udgiv/publikatio ner/2000/87-7944-302-8/pdf/87-7944-303-6.pdf. Accessed 9 Apr 2018

51. Yang X, Ng W, Shu B, Wong E, Hun G, Wang C (2019) Characterization and ecotoxicological investigation of biochar produced via slow pyrolysis: effect of feedstock composition and pyrolysis conditions. J Hazard Mater 365:178-185

52. Dunnigan L, Morton BJ, Eyk PJ, Van Ashman PJ, Zhang X, Anthony P, Wai C (2017) Bioresource technology polycyclic aromatic hydrocarbons on particulate matter emitted during the 
co-generation of bioenergy and biochar from rice husk. Bioresour Technol 244:1015-1023

53. Anyika C, Majid ZA, Ibrahim Z, Zakaria MP, Yahya A (2014) The impact of biochars on sorption and biodegradation of polycyclic aromatic hydrocarbons in soils-a review. Environ Sci Pollut Res 22(5):3314-3341

54. Hale SE, Lehmann J, Rutherford D, Zimmerman AR, Bachmann RT, Shitumbanuma V, Cornelissen G (2012) Quantifying the total and bioavailable polycyclic aromatic hydrocarbons and dioxins in biochars. Environ Sci Technol 46(5):2830-2838

55. Chen Z, Chen B, Chiou CT (2012) Fast and slow rates of naphthalene sorption to biochars produced at different temperatures. Environ Sci Technol 46:11104-11111

56. Brendova K, Száková J, Lhotka M, Krulikovská T, Punčochář $M$, Tlustoš $P$ (2017) Biochar physicochemical parameters as a result of feedstock material and pyrolysis temperature: predictable for the fate of biochar in soil? Environ Geochem Health 39(6):1381-1395

57. Lu H, Zhang W, Yang Y, Huang X, Wang S, Qiu R (2012) Relative distribution of $\mathrm{Pb}^{2+}$ sorption mechanisms by sludge-derived biochar. Water Res 46(3):854-862

58. Yao H, Lu J, Wu J, Lu Z, Wilson PC, Shen Y (2013) Adsorption of fluoroquinolone antibiotics by wastewater sludge biochar: role of the sludge source. Water Air Soil Pollut 224:1370. https://doi. org/10.1007/s11270-012-1370-7

59. Agrafioti E, Bouras G, Kalderis D, Diamadopoulos E (2013) Biochar production by sewage sludge pyrolysis. J Anal Appl Pyrolysis 101:72-78

60. Hale SE, Hanley K, Lehmann J, Zimmerman AR, Cornelissen G (2012) Effects of chemical, biological, and physical aging as well as soil addition on the sorption of pyrene to activated carbon and biochar. Environ Sci Technol 46(4):2479-2480

61. Gan C, Liu Y, Tan X, Wang S, Zeng G, Zheng B, Liu W (2015) Effect of porous zinc-biochar nanocomposites on $\mathrm{Cr}(\mathrm{VI})$ adsorption from aqueous solution. RSC Adv 5(44):35107-35115

62. Thommes M, Kaneko K, Neimark AV, Olivier JP, Rodriguez-Reinoso F, Rouquerol J, Sing KSW (2015) Physisorption of gases, with special reference to the evaluation of surface area and pore size distribution (IUPAC Technical Report). Pure Appl Chem 87:1051-1069

63. Leng L, Yuan X, Huang H, Shao J, Wang H, Chen X, Zeng G (2015) Bio-char derived from sewage sludge by liquefaction: characterization and application for dye adsorption. Appl Surf Sci 346:223-231

64. Jindo K, Mizumoto H, Sawada Y, Sanchez-Monedero MA, Sonoki T (2014) Physical and chemical characterization of biochars derived from different agricultural residues. Biogeosciences 11(23):6613-6621

65. Hossain MK, Strezov Vladimir V, Chan KY, Ziolkowski A, Nelson PF (2011) Influence of pyrolysis temperature on production and nutrient properties of wastewater sludge biochar. J Environ Manage 92(1):223-228
66. Lu H, Zhang W, Wang S, Zhuang L, Yang Y, Qiu R (2013) Characterization of sewage sludge-derived biochars from different feedstocks and pyrolysis temperatures. J Anal Appl Pyrolysis 102:137-143

67. Jin J, Li Y, Zhang J, Wu S, Cao Y, Liang P, Christie P (2016) Influence of pyrolysis temperature on properties and environmental safety of heavy metals in biochars derived from municipal sewage sludge. J Hazard Mater 320:417-426

68. Essien JP, Ebong GA, Asuquo JE, Olajire AA (2012) Hydrocarbons contamination and microbial degradation in mangrove sediments of the Niger Delta region (Nigeria). Chem Ecol 28(5):421-434

69. Semple KT, Riding MJ, McAllister LE, Sopena-Vazquez F, Bending GD (2013) Impact of black carbon on the bioaccessibility of organic contaminants in soil. J Hazard Mater 261:808-816

70. Lehmann J, Rillig MC, Thies J, Masiello CA, Hockaday WC, Crowley D (2011) Biochar effects on soil biota-a review. Soil Biol Biochem 43(9):1812-1836

71. Derrien M, Lee YK, Park JE, Li P, Chen M, Lee SH, Lee SH, Lee JB, Hur J (2017) Spectroscopic and molecular characterization of humic substances (HS) from soils and sediments in a watershed: comparative study of HS chemical fractions and the origins. Environ Sci Pollut Res 24(20):16933-16945

72. Lesage S, Brown S, Millar K, Novakowski K (2001) Humic acids enhanced removal of aromatic hydrocarbons from contaminated aquifers: developing a sustainable technology. J Environ Sci Health Part A 36(8):1515-1533

73. Simpson MJ, Chefetz B, Hatcher PG (2003) Phenanthrene sorption to structurally modified humic acids. J Environ Qual 32:1750-1758

74. Seibel F, Heidenreich S, Frimmel FH (1996) Interaction of humic substances and polycyclic aromatic hydrocarbons (PAHs) during the degradation of PAHs. Acta Hydrochim Hydrobiol 24(6):260-266

75. Talley JW, Ghosh U, Tucker SG, Furey JS, Luthy RG (2002) Particlescale understanding of the bioavailability of PAH in sediment. Environ Sci Technol 36(3):477-483

76. Inam E, Offiong N, Essien J, Kang S, Kang S, Antia B (2016) Polycyclic aromatic hydrocarbons loads and potential risks in freshwater ecosystem of the Ikpa River Basin, Niger Delta-Nigeria. Environ Monitor Assess 188:49. https://doi.org/10.1007/s1066 1-015-5038-9

77. Ogbonnaya U, Semple K (2013) Impact of biochar on organic contaminants in soil: a tool for mitigating risk? Agronomy $3(2): 349-375$

Publisher's Note Springer Nature remains neutral with regard to jurisdictional claims in published maps and institutional affiliations. 